\title{
Children and teenagers living in orphanages victims of violence: dilemmas and nursing perspectives
}

\author{
Crianças e adolescentes abrigados vítimas de violência: dilemas e perspectivas da \\ enfermagem
}
Niños y adolescentes abrigados víctimas de violencia: dilemas y perspectivas de la enfermería

Paloma Reschke Salomão ${ }^{1}$, Wiliam Wegner ${ }^{2}$, Simone Travi Canabarro ${ }^{3}$

This article aimed to understand the nursing care provided to children/teenagers victims of violence living in orphanages and to identify the strategies used on the treatment of these individuals when they arrive at the institution. Qualitative, exploratory-descriptive study conducted from March to April 2012, at the headquarters of the Fundação de Proteção Especial do Estado do Rio Grande do Sul [Special Protection Foundation of the State of Rio Grande do Sul] in the city of Porto Alegre, Brazil. The data were collected through focus group in three meetings with seven nurses from the mentioned institution. The analysis of the information followed the proposed theme, identifying three categories: violence conceptions and vulnerability factors, nursing care provided to children/teenagers victims of violence and violence prevention in orphanages. Conclusions point out that attendance protocols are fundamental for integral care and that recreational content may be a strategy for taking care of children/teenagers victims of violence.

Descriptors: Child; Adolescent; Violence; Shelter; Child Advocacy.

Objetivou-se compreender os cuidados de Enfermagem oferecidos a crianças e adolescentes vítimas de violência em situação de abrigamento e identificar as estratégias utilizadas no atendimento destas vítimas na chegada à instituição. Estudo qualitativo, de cunho exploratório-descritivo, realizado de março a maio de 2012, na sede da Fundação de Proteção Especial do Estado do Rio Grande do Sul, Porto Alegre, Brasil. Os dados foram coletados por meio de grupo focal em três encontros com sete enfermeiros da referida Fundação. A análise das informações seguiu a proposta temática, identificando três categorias: concepções de violência e fatores de vulnerabilidade, cuidados de Enfermagem prestados a crianças e adolescentes vítimas de violência e prevenção da violência nas instituições de abrigamentos. As conclusões apontam que os protocolos de atendimento são fundamentais para o cuidado integral e que o lúdico pode ser uma estratégia de cuidado para crianças e adolescentes vítimas de violência.

Descritores: Criança; Adolescente; Violência; Abrigo; Defesa da Criança e do Adolescente.

El objetivo fue comprender y describir la atención de enfermería ofrecida a niños/adolescentes víctimas de violencia en situación de abrigo e identificar las estrategias utilizadas en su atendimiento al llegar a la institución. Estudio cualitativo, exploratorio-descriptivo, realizado entre marzo-mayo de 2012, en la sede de la Fundación de Protección Especial del Estado del Río Grand del Sur, en Porto Alegre, Brasil. Los datos fueron recolectados por enfoque grupal en tres encuentros con siete enfermeros de la Fundación. El análisis de las informaciones siguió la propuesta temática, identificando tres categorías: concepciones de violencia y factores de vulnerabilidad, atención de enfermería prestada a niños/adolescentes víctimas de violencia y prevención de la violencia en las instituciones de abrigo. Las conclusiones apuntan que los protocolos de atendimiento son fundamentales para la atención integral y que el lúdico puede ser una estrategia de cuidado para niños y adolescentes víctimas de violencia.

Descriptores: Niño; Adolescente; Violencia; Abrigo; Defensa del Niño y del Adolescente.

\footnotetext{
${ }^{1}$ Centro Universitário Metodista do Instituto Porto Alegre. Porto Alegre, RS, Brazil.

${ }^{2}$ Universidade Federal do Rio Grande do Sul. Porto Alegre, RS, Brazil.

${ }^{3}$ Universidade Federal de Ciências da Saúde de Porto Alegre. Porto Alegre, RS, Brazil.

Corresponding author: Wiliam Wegner

Rua São Manoel, 963, Rio Branco, CEP: 90620-110. Porto Alegre, RS, Brazil. E-mail: wiliam.wegner@ufrgs.br
} 


\section{Introduction}

Children and adolescents, victims of domestic violence, whether physical, psychological, sexual or due to neglect, need care that can fulfill their needs. Taking them to an orphanage can be the most common action adopted by institutions that defend the rights of children and adolescents for their protection.

Care presupposes the relationship between human beings (the caregiver and the persons who receives care) and it challenges people's skills to use this technology that builds a routine. Through mutual cooperation between subjects, care can be expressed through language, body, interactions, and/or the ability to see and feel the world ${ }^{(1)}$.

Investments in the health of children and adolescents are cost-effective for the Ministry of Health, since promoting quality of life is to ensure energy and the creative, innovative and constructive spirit of the young population, which should be considered as a rich potential capable to influence positively the development of the country ${ }^{(2)}$.

The protective measure called orphanage is described by the Statute of the Child and Adolescent as a temporary and exceptional strategy, usable only as a transitory way to take children and adolescents at risk to a substitute family ${ }^{(3)}$.

The arrival of new children to an orphanage causes countless changes in the routine of these places as well as in the behavior of other children who live there. The nursing staff has an important role regarding the need for follow-up and to take these children to the care network where they will be attended. Their entrance in the institution is a responsibility of the social services, but the health care control and the review of procedures performed are a duty of nursing professionals.

The vulnerability of children and adolescents overcomes many barriers, such as size, strength or age being connected to social practices. Many spaces have been created with the aim of their full protection, but they ended up becoming reference of scandals in violation of their rights ${ }^{(4)}$. These characteristics are present in the context of institutionalized children and adolescents who remain in orphanages.

An important milestone in the history of institutionalization of children and adolescents occurred with the article 227 of the Federal Constitution of 1988, which claims to be the duty of the family, society and the government to ensure children and adolescents, with absolute priority, to live with their families and community, besides keeping them safe from all forms of negligence, discrimination, exploitation, violence, cruelty and oppression ${ }^{(5)}$.

National epidemiological data highlight the causes of unnatural death, such as violence, being the first cause of death in the age group from zero to 19 years old (39.7\%), even with a significant proportion in the age group from 15 to 19 years old (55.1\%) across the country ${ }^{(6)}$.

The number of children and adolescents victims of violence is high and, with this, their entry into orphanages has increased proportionately to situations of abuse experienced by these children. The sheltering institution is an important measure of protection, but it can also be a vulnerability factor for children and adolescents victims of violence, since violence situations can be repeated in this scenario.

Receiving and cherishing children who are often forcibly removed from their family environment is a difficult, arduous job and it requires tolerance, respect and a lot of empathy. Working with different people from different sectors in pursuit of a common ideal, such as growth, comfort and quality of life of those who were sheltered is crucial in order to produce an integral care element, which can maintain the same guidelines and same precepts on their difficulties, offering dignity, respect and guaranteeing their healthy growth and development.

The response to violence must be followed by a 
process of intersectoral discussions that contribute to give more visibility to the problem and allow the use of broader strategies ${ }^{(1)}$.

Nursing has an important role to advance on the precariousness of health care provided to these children. Thus, it is important that there is a reorganization of nursing actions more contextualized to the life-health situation of these people, which can deal through an expanded look, with all their needs, that in addition to physical damage, carry with them severe psychological damages.

Health activities of the nursing team from orphanages, due to situations of violence, need to be described so that they can broaden the understanding of this phenomenon, which questions the attitudes developed by the health team on the arrival of children and adolescents victims of violence to the institution.

Faced with this problem, the following question arose: how is the experience of nurses who work in orphanages concerning the care they perform as part of a network of attention to children and adolescent victims of violence?

The objectives of this study were to understand the nursing care offered to children and adolescents victims of violence living in orphanages and identify the strategies used to treat these victims upon arrival at the institution.

\section{Method}

This is an exploratory, descriptive and qualitative study. A qualitative research is a procedure of reflection and analysis of reality through the use of devices and techniques for detailed understanding of the object of study, including cultural values, historical processes and the internal logic of groups, institutions and actors. A descriptive research aims to analyze, observe, record and correlate facts or phenomena without changing them, getting to know the many situations and relationships that occur in social life. An exploratory study aims to give a general explanation on a particular subject, by means of a wider investigation $^{(7)}$.

The research was conducted at the headquarters of the Foundation for Special Protection of Rio Grande do Sul in Porto Alegre-RS and established by Decree No. 41 615, from 29/05/2002, linked to the Secretaria do Trabalho, Cidadania e Assistência Social [Secretary of Labor, Citizenship and Social Assistance]. It is a public institution of private law with the aim to administer the implementation of measures of institutional care focused on children and adolescents who were victims of abandonment, abuse, physical and psychological violence or neglect, therefore, being in a situation of social vulnerability. The mentioned foundation has seven nurses responsible for eight different units of residential shelters. All nurses linked to the areas of shelter from the foundation were selected, thus totaling seven participants.

Inclusion criteria for the participants were: perform medical work as a nurse in the health of children and adolescents and work with them for, at least, six months. The exclusion criterion adopted was professionals who were away from work due to vacation or sick leave.

The strategy of information collection was the focus group, which was organized and structured by a script (book) containing questions for debate among members of the group in three previously scheduled meetings. The focus group constitutes a kind of interview or conversation held in small groups. To be successful, it needs to be very well outlined, since they aim to obtain information, deepening the interaction among participants, either to generate consensus, or to explain differences. The technique should be applied by a script that goes from the general to the specific, in a nondirective environment, coordinated by a moderator capable of achieving people's participation and their point of view, looking for a deeper discussion ${ }^{(7)}$. 
The meetings were previously scheduled according to the availability of the participants and held at the institution, ensuring privacy between the researcher and the researched group. Three meetings were performed using the focus group technique. The first meeting had as its main subject the conceptions of violence and vulnerability factors, highlighting in the discussion the concepts of violence from the nurses' perspective, the types of violence committed, the classifications and the main factors involved; the second meeting discussed the nursing care provided to children and adolescents who were victims of violence, the procedures adopted by the nursing staff in relation to suspected sexual abuse that happened inside and outside the institution, understanding of the nursing staff regarding the care offered and how these children should be protected; and the third meeting was about prevention of violence in the sheltering institutions, the main demands of care provided, the definition of priorities and the basis for protection of children and adolescents.

The meetings were audio-recorded and, soon after, transcribed, followed by data analysis. For information analysis, the technique of thematic analysis was used, whichallows one to validate, through specialized and scientific procedures, data from a text in a given context. Thematic analysis has three steps: Pre-analysis, material exploration and processing of results obtained and their interpretation ${ }^{(7)}$.

The process of analyzing the information generated three thematic categories: conceptions of violence and vulnerability factors; Nursing care provided to children and adolescents victims of violence; and prevention of violence in orphanages.

For coding purposes, the focus groups were grouped into G1, for first focus group; nurses were represented by the letter $\mathrm{N}$, plus a numeric digit (N1 = Nurse 1); and fragments of analysis of each group discussion were symbolized by MU (Meaning Unit), followed by a digit number (MU3 = Meaning Unit 3).

Ethical issues were observed. All participants signed a consent form, which detailed all the procedures performed, including the risks and benefits that their participation can generate.

The project was submitted and approved by the Ethics Committee in Research of the Centro Universitário Metodista do Instituto Porto Alegre [Methodist University Centre of Porto Alegre Institute] under number 312/2011.

\section{Results}

The data analysis allowed one to point out the difficulties related to the monitoring of institutionalized children and adolescents, as well as understanding the attitudes and behaviors practiced by nurses in the everyday practices of health care offered to these children. The following are the themes of the study.

\section{Conceptions of violence and vulnerability factors}

It was observed, in the first meeting, by reports of the majority of the nurses that most of the violence done towards institutionalized children and adolescents occurs within the institution, resulting from psychological violence committed by professionals who work in the shelters, which can be seen in the statements below: The moral and psychological violence to me are the worst kinds of violence... Oh, do not come near me, because your mouth smells like a sewer, go brush your teeth first ... (G1N1MU1). For me it is the issue of institutional bullying... Attacks said among children and between staff and children (G1N2MU2). Emotional abuse, this psychic thing, these are the most harming to the children. These occur all the time inside the orphanage (G1N1MU24).

It was identified that the professionals' tiredness can characterize the violence committed in the orphanages. This can be considered a vulnerability factor related to professionals. About this, two participants commented that often the violence happens due to a lack of staff and to their working hours in the institution, which entails heavy workload 
and increased stress level of those who should take care of the institutionalized children and adolescents. This testimony contextualizes this: What... contributes to violence inside the orphanage is the employees' stress, few people to work (G1N6MU26). Over time employees end up all getting sick because they've already worked many years in the same institution, and the children are now treated as objects and not as children (G1N4MU33).

Nurses pointed out being aware that, in addition to psychological violence, sexual abuse cases also occurred, showing fragility and vulnerability of minors in institutions that should serve as shelters and protection. The work of professionals in daily regular hours, added to extra hours necessary by the lack of staff in the orphanages, causes extreme wear and stress of the whole multidisciplinary team, which interferes with attention to the daily needs of institutionalized children and adolescents.

\section{Nursing care provided to children and adolescents victims of violence}

In the second meeting, the nurses discussed the fact that they do not know how to act when a child is a victim of violence - in this case, sexual violence and is taken to the orphanage. It was mentioned that the priority in the care provided meets the personal precepts of each professional, so it is observed a lack of protocols and routines to the care for this portion of the public attended.

Understanding the violence phenomenon in a scientific way is an initial step to deconstruct its trivialization and add greater reflection and seriousness to this theme. The lack of protocols and the lack of guidance in the care of institutionalized children and adolescents are shown in the dialogues below: We don't do anything. I think there isn't a protocol, each professional does it the way he thinks he should, the way they think they have to do (G2N2MU35). But that's the big problem, it depends on what each one thinks he should do, the concept of each individual. This family I will attend, this one I won't (G3N2MU90).
At another point of discussion, one came up with the problem related to the way these children and adolescents manifested themselves about the situations of violence that they experienced in their homes and/or at the institution that housed them. The reflection of violence may persist in different contexts and involve many different factors, but it is essential to break the cycle and articulate care networks available for it. These statements illustrate this point: I remember a boy who suffered abuse from his father and who said at the shelter that he thought that what happened inside his house was normal because it was a family practice (G2N4MU42). Many of the children live in situations of violence and it is not only sexual violence, it is economic, you know, because the vast majority of them do not have even basic sanitation. So all this somehow contributes to disturbed relationships (G2N5MU41).

Violence and sexual abuse are directly linked to the fact that these children and adolescents are extremely needy of affection and do not discern what it is to have a father, or another family member, as a model or abuser. The strategies employed by victims of sexual violence can put teenagers as victims and aggressors, because they can do it for believing that this form of social relationship is acceptable in the context where they live and were raised. The perception of participants shows that: When they have almost the same age, I think there are sex games, depending on how they see this, because oral sex is what they often do, it is a way of being touched, because there is a great affective need and that's the way they find to be closer to each other. It has a lot to do with the emotional part, with the abandonment that they suffered, with loneliness, emptiness (G2N5MU43). And for her it is nice to have her body exposed, showing her belly and show a little her breasts and she feels important because she realizes that the boys look at her and then she feels a bit ugly, but then she shows her breast a little and then she sees that boys get a little more interested... (G2N7MU57).

In another context, nurses reported what is important in the care of these children, emphasizing that playing is extremely important in preserving childhood, little experienced by them, but essential to their growth. This report stresses this aspect: It is 
important to show them other relationships, right? how playing is important and sometimes even build the game, because many of these children do not know how to do it. And from this construction maybe he can create a fantasy world with symbols, right? (G2N1MU51). What I always try is to follow the technical standards for their reception. When children come here, in their heads, everything went wrong. So what they don't need when they get here is very strict rules and a very hostile treatment. They need to play, learn how to do this, right? (G2N5MUUS44).

\section{Prevention of violence in sheltering institutions}

In the third focus group, the importance of mothers and/or families to be heard and supported along with the children was reported, as it will be for that context that minors will return after passing through the orphanage or turning 18: I think that the family should always be in the foreground, because it will probably be for this family that these children will return afterwards (G3N1MU81). I think the mother has to be heard. We have a family group that deals with these issues of abuse within the family. It is a very sick, complicated relationship to treat. It is important to listen to the family also because the record does not provide all the information, and sometimes from the dialogue we can remove a lot of other information that were not described on the paper (G3N1MU92).

In this study, nurses reported that children/ teens from the institution need care that is first based on the empathy and welcoming dialogue, so that they can feel comfortable, protected and free to expose their greatest fears and limitations, two participants highlighted that: There is a great poverty in them in all the senses, values, feelings, life, everything. And when they arrive it is important to talk to the children and make them feel comfortable with us, we have to make them feel well to be close to us and thus better open themselves and expose their anxieties and fears. For me what is the most important is the personalized service... (G3N5MU100). They have to feel welcomed, at ease with us. Idealistically, at home! (G3N7MU102).

Participants emphasized that the interpersonal relationship, posture and behavior of the professionals involved in the care for victims is an opportunity to illustrate contrary alternatives to violence for those involved.

\section{Discussion}

The family violence is the third leading cause of mortality in the population in general and the leading cause of death among children and adolescents over one year old. Physical aggression (violence) is characterized as the fourth leading cause of mortality among children aged from zero to nine months, and this profile is repeated in adolescents between 15 and 19 years old, in which $58.7 \%$ of deaths were due to violence $^{(6,8)}$.

The Ministry of Health classifies violence against children and adolescents as domestic violence, which is configured as a subdivision of interpersonal violence. One also noticed that there are four different types of nature that characterize violent $\operatorname{acts}^{(8)}$, described below. Understanding these concepts is fundamental to the identification and understanding of the phenomenon of violence in shelters.

Physical violence, such as any violent action with use of physical force intentionally, not accidental, practiced by parents, guardians, relatives or acquaintances of the child or adolescent, can hurt, injure, cause pain and suffering or destroy the person, leaving or no obvious marks on the body; psychological violence is any act that harms or endangers self-esteem, identity or development of the child/adolescent. It manifests itself in the form of rejection, depreciation, discrimination, disrespect, excessive demands, humiliating punishments and their use welcoming the psychic needs of others; sexual violence is any act or sexual play with intent to stimulate sexually children or adolescents, aiming to use them to obtain sexual satisfaction, in which abusers are in a more advanced stage of psychosexual development than the victim; neglect is characterized by omissions of adults (parents or others responsible for the minor, including institutions) by failing to 
provide basic necessities for the physical, emotional and social development of children and adolescents ${ }^{(8)}$.

The concept of violence and their natures were discussed since the first meeting, so that participants could understand the characteristics and vulnerability factors involved in the care for victims of violence. One observed a difficulty in the identification and classification of violence among those surveyed. The reflections produced pointed to vulnerability factors that predispose children and adolescents to suffer some kind of violence, such as family relationships, socioeconomic status, education level, among others.

In the dialogues several factors related to the way psychological violence happens came up, the most cited by nurses occurs in institutions, making it clear that, many times, the place that should serve as a protection and shelter to institutionalized children ends up being the place of biggest assaults committed against them.

It is important to note the violence within relationships, not being seen as a disease of the aggressor or the victim, but a consequence of a complex relational dynamic, becomes an important social problem that has effects from which may derive severe harm to health ${ }^{(9)}$.

When one problematizes the phenomenon of violence in the care of institutionalized children and adolescents, it is essential to make visible to the team of professionals that victims of health problem are the minors, so one cannot allow employees to express their dissatisfaction, damaging or limiting care to minors who were victims of violence. It is up to the professionals involved to look in other spaces for a guarantee that their claims will be heard, without interfering with the care received ${ }^{(4.6)}$.

Job stress occurs when the difficulties of communication and the interpersonal relationships do not find adequate space and time to be identified and developed, thus generating conflicts and consequences, such as aggressiveness, covert or explicit resistance, discouragement, disbelief and carelessness. Feelings of care, warmth, acceptance, support and cohesion stop being valued among team members ${ }^{(10)}$. It is essential to minimize these vulnerability factors related to professionals for the prevention of institutional violence.

The phenomenon of psychological violence, as well as the stress of the staff of orphanages, highlights the need to improve the skills of employees, and so a better relationship of bond between institutionalized children and the staff( ${ }^{(4)}$.

The relationship between vulnerability and rights of children and adolescents shows not the idea of incapable subjects, but the intention to block the actions that prevent them from living their childhood. So if they do not have their rights guaranteed, they are even more vulnerable because their relationships will be based on the perception that they do not have them ${ }^{(4)}$.

It is important to contextualize that the way most approaches to cases involving violence against children and adolescents are performed reflects the lack of coordination of network services and the lack of integration among professionals of the institution, which causes several untimely and unfavorable procedures to the management and care of children and adolescents taken to orphanages ${ }^{(8)}$.

For such situations, the Ministry of Health elaborated a technical manual, aiming to equip health professionals for assistance to violence ${ }^{(11)}$. Thus, each institution that provides care to this segment of users should use as a reference to care the guidelines of this manual, worrying to empower vehemently the multidisciplinary team of care to minors.

It is important to highlight that the family environment is presented as the biggest scenario of expression of violent acts committed against children and adolescents. These minor, subjected to intentional and repeated violence, introject these patterns as "truths", replicating this experience in their social relations, naturalizing violence. Such an event can be perpetuated in the family, establishing itself as a violent event ${ }^{(9)}$.

The relationships of children and adolescents 
taken to institutions might present perverse relationships that demonstrate their need of affection, lack of self-esteem and love towards other people, emphasizing the need to find subsidies and values that reflect guidelines for the reality of each one of them. Because of this, it is important to overcome the barriers that limit the welcoming and the social reintegration of victims of violence, equipping the professionals involved in the education perspective, redefining the value of life and strengthening their self-esteem $^{(1)}$.

Playful actions can assume different roles in children's development. It can be stated that the function of playing for children is to create ways for their overall development (social, cognitive, emotional and psychomotor), departing from imaginary situations, social interactions and concrete elements, forming relationships with the world and constructing knowledge about it and about themselves ${ }^{(12)}$. Strategies that employ playful actions as a reference in the care of children/adolescents victims of violence reinforce the intention to discuss new possibilities from games. However, professionals who work in this scenario should serve as a reference and encourage playing.

Thus, it is essential that these minors (re) learn how to play, creating a fantasy world in which they can establish, through games, a space for dealing with their conflicts and then show more clearly their difficulties. Confronting violence requires from people to occupy themselves with complex issues involving ethics, morality, ideology, politics, culture, among other factors for acquisition of proactive attitudes, awareness and mobilization actions in defense of the rights of children and adolescents. This debate should take place in schools, communities, health services and in their families, as they contribute to the full protection of victims of violence ${ }^{(6)}$.

In the conception about the prevention of violence in orphanages, the importance of the presence of families in the treatment of these children was emphasized. According to the situation of violence it is necessary for the health team to bring together actions interfaced with other policies for restoring their rights to have social and family harmonious coexistence ${ }^{(3,5-6)}$.

The approach and the involvement with the family of children and adolescents victims of violence need to be a concern and agenda of the health care team. The therapeutic approach to these children implies the need to provide support and interventions with less risk to their physical integrity. Fighting the effects of violence on children's health takes these professionals and nurses, in particular, to develop creative strategies to deal with violence as a complex social problem ${ }^{(13)}$.

It is important to avoid judgments and comments of warning, anger, blame or accusation and confrontation. In the interview with those responsible for the children, an empathic relationship is crucial, making it clear that the ultimate goal is the protection of the children and adolescents, maintaining a consistent professional attitude coherent with ethics and rights ${ }^{(14)}$.

Although the care offered by a team is not very effective in orphanages, it is clear the importance of an empathic and close relationship between the healthcare team and the children and their families. This relationship will facilitate the maintenance of bonds among the minors' families, and a way to overcome better the effects of violence in their growth and development. It must be remembered that children and adolescents found in orphanages are there because they experienced some kind of domestic violence, with losses in their well-being, physical and psychological integrity, among others ${ }^{(15)}$.

The orphanage consists of a place extremely important for children and adolescents because it is an environment where a number of functions, activities and interactions are performed. The affective dimension is an inherent part of human relationships and therefore should not be excluded as 
a favorable element of development, balance, power and affection ${ }^{(14)}$. Adults are not always sensitive and willing to listen to them, respect them and, above all, welcome them in their wisdom and joy, to deal with the peculiar hardships of this problem ${ }^{(16)}$. Thus, it is emphasized that the professional team should ensure and guarantee the rights of institutionalized children and adolescents; and maybe the first step is to welcome and protect minors of the recurrence of the violations that they were submitted to. Furthermore, it is important that professionals include in their actions the perspective of health education aiming at the full child care to overcome the biomedical model previously established ${ }^{(17)}$.

It is essential to know the resources for the protection of childhood and adolescence as the Guardian Council, Civil Police Station, health policies, and especially educational policies that work in the monitoring of children/adolescents, in order to verify their daily life and enable their healthy sociability ${ }^{(18)}$.

The position of nurses who have insertion in different settings of care to children and adolescents, provides a significant contribution in the detection, prevention and reporting of the phenomenon of violence ${ }^{(19)}$. In addition, nurses have an essential role in maintaining the physical and mental health of the institutionalized children, because they are the ones who will work together with the entire network of care available to these children and adolescents. Added to this, a commitment to recognize that this care should be grounded in a social safety network, where there is solidarity and cooperation between organizations, so that decisions can be taken horizontally within the principles of equality ${ }^{(8)}$. Therefore, it becomes essential that minors recognize shelters as a legitimate space that enables security and protection.

\section{Final Considerations}

Children and adolescents who have experienced violence should be considered participating subjects in the different dimensions of care that is provided to them. Their speeches, needs and desires must be understood in order to assess and adapt the actions of the service to their individual needs.

The use of ludic actions in the treatment of children victims of violence is an important behavior, so that they can learn how to create their spaces and social ties, and then feel confident and able to find solutions to their problems. The treatment of a serious issue such as violence, if well conducted, can contribute to the recovery of self-esteem, for the recovery of the children, their social network and their rights.

Care for physical and mental health is still restricted, and little is done about the encouragement of a future project, since they represent exceptions in the strategies of reintegration to family life, giving little emphasis to the importance of affect as a propellant factor of development, growth and education of minors.

The promotion of participative spaces, which involve professionals, children, adolescents and their families, will facilitate the establishment of relationships of trust with a multidisciplinary team of health care for those users. Thus, children will be able to reveal in a better way the circumstances of the violence situations experienced both outside and inside orphanages.

Nurses should prioritize the full protection of children and adolescents on their arrival at an orphanage and plan nursing care guided by this principle. The empirical and personal approach does not subsidize the preparation of nurses and staff to act with scientific basis. It is urgent the use of care protocols with victims of violence and the instrumentalization of professionals with specific characteristics of the children's world aiming at integral care. The study demonstrated that the experience of nurses in this scenario lacks scientific basis and development of the phenomenon violence by all the members of the staff, justifying the need for a multidisciplinary approach 
also of professionals who deal with it and have shown difficulties to work in these circumstances.

So, one highlights the relevance of creating protocols and service flows in shelters since the teams are not properly trained and oriented towards the articulation of the health service and other services in the network, which will serve as benchmarks to maintain the health and growth of institutionalized children.

\section{Collaborations}

Salomão PR contributed to the study conception, literature review, collection and analysis of data and writing of the article. Wegner $\mathrm{W}$ contributed to the study design, data analysis, critical revision and final editing of the article. Canabarro ST contributed to the review, revision and final editing of the article. All the authors contributed to the critical revision and approval of the version to be published.

\section{References}

1. Penna LHG, Carinhanha JI, Leite LC. The educative practice of professional caregivers at shelters: coping with violence lived by female adolescents. Rev Latino-Am Enfermagem. 2009; 27(6):981-7.

2. Ministério da Saúde (BR). Diretrizes Nacionais para a Atenção Integral à Saúde de Adolescentes e Jovens na Promoção, Proteção e Recuperação da Saúde. Brasília: Ministério da Saúde; 2010.

3. Conselho Nacional dos Direitos da Criança e do Adolescente. Lei no ${ }^{\circ}$ 8069. ECA - Estatuto da Criança e do Adolescente. Brasília: CONANDA; 2010.

4. Poletto M, Koller SH, Dell'Aglio DD. Eventos estressores em crianças e adolescentes em situação de vulnerabilidade social de Porto Alegre. Ciênc Saúde Coletiva. 2009; 14(2):455-66.

5. Brasil. Constituição 1988. Constituição da República Federativa do Brasil. Título VIII - Da ordem social, Capítulo VII - Da Família, da Criança, do Adolescente, do Jovem e do Idoso. Brasília: Senado; 2013.

6. Ministério da Saúde (BR). Impacto da violência na saúde das crianças e adolescentes: prevenção de violências e promoção da cultura de paz. Brasília: Ministério da Saúde; 2010.

7. Minayo MCS. O desafio do conhecimento: pesquisa qualitativa em saúde. 11aㅡ ed. São Paulo: Hucitec; 2008.

8. Ministério da Saúde (BR). Linha de cuidado para atenção integral à saúde de crianças, adolescentes e suas famílias em situação de violências. Brasília: Ministério da Saúde; 2010.

9. Nunes CB, Sarti CA, Ohara CVS. Conceptions held by health professionals on violence against children and adolescents within the family. Rev Latino-Am Enfermagem. 2008; 16(1):136-41.

10. Campos EP, Chaves AN, Pereira CM, Fontaine JAL, Santos LJ, Cardoso LMF, et al. Equipes do programa saúde da família: estresse profissional e dinâmica de trabalho. Rev APS. 2010; 13(1):46-54.

11. Ministério da Saúde (BR). Metodologia para o cuidado de crianças, adolescentes e suas famílias em situação de violências. Brasília: Ministério da Saúde; 2011.

12. Rosa FV, Kravchychyn H, Vieira ML. Brinquedoteca: a valorização do lúdico no cotidiano da pré-escola. Barbarói. 2010; 33:8-27.

13. Pierantoni LMM, Cabral IE. Crianças em situação de violência de um ambulatório do Rio de Janeiro: conhecendo seu perfil. Esc Anna Nery. 2009; 13(4):699-7.

14. Siqueira AC, Dell'Aglio DD. Crianças e adolescentes institucionalizados: desempenho escolar, satisfação de vida e rede de apoio social. Psic Teor Pesq. 2010; 26(3):407-15.

15. Ferreira FPM. Crianças e adolescentes em abrigos: uma regionalização para Minas Gerais. Serv Soc Soc. $2014 ; 117: 142-68$.

16. Monteiro EMLM, Brandão Neto W, Moisalye I. Violência contra criança e adolescente: rompendo o silêncio. Rev Rene. 2009; 10(3):107-16. 
17. Bezerra KP, Monteiro AI. Violência Intrafamiliar contra a criança: intervenção de enfermeiros da Estratégia Saúde da Família. Rev Rene. 2012; 13(2):354-64.

18. Miranda ACT, Lima ES, Maio ER. Instituições sociais: as interfaces entre escola e CREAS sobre a violência sexual contra crianças. Rev Educ Cult Soc. 2013; 3(2):271-82.

19. Carvalho QCM, Cardoso MVML, Silva MJ, Braga VAB, Galvão MTG. Violência contra crianças e adolescentes: reflexões sobre políticas públicas. Rev Rene. 2008; 9(2):157-64. 